\title{
II. Description of a new reflecting compass
}

\section{Mr. T. Jones}

To cite this article: Mr. T. Jones (1815) II. Description of a new reflecting compass, Philosophical Magazine Series 1, 46:207, 7-9, DOI: 10.1080/14786441508638481

To link to this article: http://dx.doi.org/10.1080/14786441508638481

曲 Published online: 27 Jul 2009.

Submit your article to this journal $2 \pi$

Џ Article views: 2

Q View related articles $₫$ 
the centre of the egg. These shells are wholly extra-vasculat. and their albuminous membranes are alike cuticular, whilst the inner true membrana putaminis is made reticular and capable of vascular organization. The order of deposit in these examples is like that of enamel in teeth, which appears to be precipitated upon the bone of the touth under the guidance of a membranous case or mould. From a disordered fowl, I have seen eggs produced the calcareotis crusts of which were inflated with bubbles, so as to form a cancellated shell in texture like pumicestone. The most durable substances of animal bodies, such as the bones and teeth, are only partly vascular, since their calcareous materials are fixed by chemical precipitants, and remain under chemical laws. Injuries done to the homs of cattle, to the hoofs of animals, and to human nails, are never restored; those parts do not possess the power of self-repair, and it is only by mechanical wearing away that such injuries are obliterated. Indeed, the beneficent construction of animal nature is sufficiently manifested in the insensibility of all the exuvial coverings, and in the inorganic composition of many parts which are exposed to mechanical attrition; as the enamel of teeth, the horny beaks of birds, and the cuticular or horny coverings of feet. The same beneficence appears to be extended to many parts of the external organic substances by which painful sensations are obviated; while the substances themselves, being left directly under the dominion of the vital superintendancy, become more permanent:- -such parts are the tendous ligaments, cartilages, cellular tissue, the gelatine and lime of bones. Even water is an essential constituent of the animal fluids, and affords the necessary softness and flexibility to the solids.-But this subject and its connexion with the vegetable composition and texture extends far beyond the limits of a memoir, and I must therefore suspend my observations.

[To be continued.]

\section{Description of a new Reflecting Compass. By $M r$. T. Jones, 62, Charing Cross, London.}

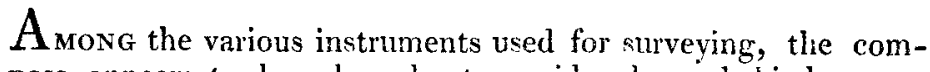
pass appears to have been least considered; and this has probably arisen from its want of portability when furnished with a stand, and the conviction that under the most favouralle circumstances it is far inferior to the theodolite; and yet requires equal care in its adjustment and use.

But in military sketching, in the delineation of roads, rivers, \&c. and in all surveys where rapidity is more an object than $\epsilon x-$ treme accuracy, the compass will be found a most valuable aux- 
iiary, as it possesses the advantage peculiar to itself, of determining the point of station by the bearings of two objects only, the positions of which are known; and may even in certain confined circumstances be employed in determining the station of the observer by the bearing and estimated distance of one known object.

These considerations led to the construction of the instrument which I am about to lescribe. It was invented in 1811 by Captain Kater, F.R.S.: and on a survey made with it the same year, was founk capable of a degiee of accuracy beyoud any expectation that had been previously formed of it.

The box containing the compass is about $2 \frac{1}{2}$ inches diameter, but may be made of any size that may be thought convenient. Its depth is such as to allow no wore space than is sufficient for the card to foat freely. The card is very accurately divided into 260 degrees from the north towards the east, and every tenth degree is distinctly numbered. The needle, which is rendered strongly magnetical, is fixed heneath the card with its north print at the 180 th degree. It has an agate cap, and is made as light as is consistent with that form best calculated for retaining the magnetic virtue.

Fig. 1. Plate 1. represents the instrument; $A$ is the sight next the eve. It slides rather stiffly in a dovetail on the outside of the box, and is prevented by a shoulder from going beyond the bottom. Tery near the top of this sight on the inside, and projecting over the edge of the compass-card, is fixed a small plane silvered glass or mirror $B$, at an angle of about $40^{\circ}$. The mirror is of the same breadth as the sight; and when the sight is pressed home to the shoulder, the lower edge of the mirror nearly ionches the glass of the compass. Between the glass of the compass and the upper part of the mirror there is sufficient room for an opening which contains the segment of a convex lens of about three-fourths of an inch focus. In a line perpenuicular to the centre of the lens, and immediatcly above the upper edge of the mirror a small hole is dilled, through which is seen the object the bearing of which is to be determined. On the opposite part of the box is an open sight with a vertical hair cr wire : this sight is of such a length as to admit of its beingr buld down on the glass of the compass, and a contrivance is added, by which the needle is thrown of the point at the same rime, thus securing it from injury when the instrument is not in nue.

To use the Instrument.-Raise the sight, when the compasseard will viluate freely; look through the small hole above the lew: and rover the object with the thread of the opposite sight; the llue ribration of the compass-caid by incining the box, keeping 
kerping at the same time the object steadily covered by the hair; and when the card is stationary, the derree indicating the bearing (which is seen by reflection, and considerably nugnifed through the lens), may be read off to fifteen minutes by means of the hair of lise sight coming in contact with the reflected image of the divisions of the card.

Should not the divisions on the card appear distinct, the sight next the eye is to be drawn out till they are perfectly well defined. It is adviseable to tap the box gently with the finger, to lessen any friction which might prevent the needle from settling in the true direction.

In addition to ail the usual purposes of surveying to which this instrument is applicable, it may be employed with very superior advantage as an azionuth compass, or to take hearings from a boat at sea where the motion might wholly prevent the use of a compass of any ochier form; and on such occasions it will be foumd far more acerate than the largest azimuth compass of the common constriction, and its use unattended with these difficulties which frerguently give rise to erroneous results.

It wonld bo unnecessary to point ont all the various uses to which this instrument may be applied; but I may briefy observe, that as an azimuth compass it stands unrivalled, and that in land-surveying, and in the construction of maps of a country, it will be found equal in aceuracy to a large circunferentor, though suficiently portable to be carricd in the waistcoatpocket.

11. Of certain Causes which render more difficult the Discernment of the Character of the Mind from the Examination of the Organs of the Brain. By Thomas Fonsten, Esq.

\section{To Mr. Tilloch.}

Snn,- $I_{\mathrm{N}}$ pursuing the anatomy and physiology of the brain and? nervous system from the time of its, fist promulgation in Englund, I have been daily more and more convinced of the truth of the doctrine unaintained by Gatt and spuzzheim. Wiin tile evitence now before me of their correctness, it would be guite inpossible that any arguments drawn from theory should set aside a systematic arrangement of facts and a theory deduced therefrom, in the support of which I conld now acivert my mind to such a numerous hody of evidence. $\bar{I}$ have, however, in the course of my observations, noticed several causes why the apparent indication of the organs were found in a degree falicicioms; and why we did not always find the mind possessed $t^{\circ}$ encrgies commensurate to the espectation we had forined foc.n 